\title{
Food induced variation of thermal constants of development and growth of Autographa gamma (Lepidoptera: Noctuidae) larvae
}

\author{
ALOIS HONĚK ${ }^{1}$, VOJTĚCH JAROŠÍI ${ }^{2}$, ZDENKA MARTINKOVÁ ${ }^{1}$ and Ivo NOVÁK ${ }^{1}$ \\ ${ }^{1}$ Research Institute of Crop Production, Drnovska 507, CZ 16106 Praha 6 - Ruzyně, Czech Republic, e-mail: honek@vurv.cz and \\ ${ }^{2}$ Department of Zoology, Charles University, Viničná 7, 12844 Prague 2, Czech Republic, e-mail: jarosik@mbox.cesnet.cz
}

Key words. Autographa gamma, Noctuidae, larva, development, food, temperature, thermal constants, lower development threshold, sum of effective temperatures, rate isomorphy, growth, body size

\begin{abstract}
The development stages of a species may have an identical lower development threshold (LDT) and proportionally different durations. This phenomenon called "rate isomorphy" (RI) has been demonstrated for a number of insect species. In contrast, the growing day degrees accumulated over the period of larval development (sum of effective temperatures SET) should be plastic and vary with environment conditions. The prediction from RI is that, with changing conditions, the uniform LDT should be accompanied by differences in development time which remain proportional at different temperatures. This was tested by investigating the effect of diet on thermal requirements for development of larvae of the polyphagous species Autographa gamma (L.) (Lepidoptera: Noctuidae). The larvae were kept at $15.0,20.3$ and $26.7^{\circ} \mathrm{C}$ and fed on leaves of 13 dicotyledoneous herb and tree species. The proportion of total development time spent on a particular diet was plotted against temperature. The existence of RI was inferred from a zero change in development time proportion with changing temperature. This rigorous test supported RI for 3 of 9 diets where development was completed in all temperatures. The LDT observed on 11 diets where the larvae completed development in at least 2 temperatures varied between 9.3 and $11.0^{\circ} \mathrm{C}$ while SET varied between 167 and 353 day degrees (dd). Assuming RI, LDT and SET for those 9 diets were recalculated. The recalculated LDT was $10.0^{\circ} \mathrm{C}$ and SET varied between $177-257 \mathrm{dd}$. The SET increased with decreasing water content and decreasing nitrogen content of food. Worsening food quality decreased food consumption, metabolic and food conversion efficiency, and the relative growth rate of the larvae. Increasing metabolic costs of development were thus positively correlated with SET. The standardized rate of growth $\left(\mathrm{mg}_{\mathrm{g}} \mathrm{dd}^{-1}\right)$ was typical for particular diets. Pupal mass decreased with increasing temperature and, within each temperature, with development length.
\end{abstract}

\section{INTRODUCTION}

In insects the development rate (a reciprocal of development duration) increases with temperature. The increase is linear over a range of ecologically relevant temperatures, although at temperatures approaching the lower point where development ceases and at temperatures approaching the upper limits of thermal tolerance, the relationship may become non-linear. The linear relationship enables the calculation of thermal constants, such as the lower development threshold (LDT), which is a temperature at which the development rate is zero, and the sum of effective temperatures (SET), which is equal to the amount of growing day degrees (dd) needed to complete a development stage.

A huge quantity of data (reviewed by Honěk \& Kocourek 1990, Honěk 1996, Kiritani 1997) became available over the past eighty years, during which time the temperature effects on insect development have been intensively studied. The data revealed not only a large variation of thermal constants between species, but also among populations within species. However, these differences are not only caused by biological variation, but also due to bias in the experimental data. This bias appears even in carefully performed experiments and becomes enormously important when comparing the data of different authors. A recently developed method (Jarošík et al., in press) enabled a test to be made of the relevance of differences in LDT. The method consists of testing the hypothesis of "rate isomorphy". "Rate isomorphy" means that, with changing temperature, the development stages of a population of a species take constant proportions of total development time. Then the LDT is identical for all development stages. A comparison of published data for 342 species from 11 insect orders revealed "rate isomorphy" in $57 \%$ of populations. In the rest of the data violation of the "rate isomorphy" principle was very small. Thus LDT is probably uniform in developmental stages within populations and species, and probably also in taxonomically related groups of species (Dixon et al., 1997). In contrast to LDT, SET is plastic and reflects the variation in environment conditions other than temperature, including food quality of the growing stage (larva), humidity, photoperiod etc. (Squire \& Trudgill, in litt.).

With testing for "rate isomorphy" we may prove the identity of LDT of developmental stages but not to establish its correct value. A method of calculating the true LDT value may consist in looking at variation of development times of larvae of a highly polyphagous species fed with several diets. A common development threshold may be calculated using a modified application of the "rate isomorphy" principle (described in the Material and Methods). Thermal constants for development were therefore established in larvae of Autographa gamma (L.), an extremely polyphagous noctuid species occurring throughout the Europe which periodically becomes a pest of several agriculture crops. The species has 1-3 genera- 
tions per year, according to weather conditions. Its development was first described by Ostreykowna (1924) who first supposed overwintering in central Europe. Cayrol (1962, 1965) and Novák $(1971,1972,1988)$ revealed that the central European populations consist of two constituents, a part overwintering in the 4th larval instar and a part immigrating each spring from the southern Europe. The rate of larval development is influenced by temperature and humidity (Kozhantshikov, 1939; Hill \& Gatehouse, 1992), population density (Cayrol, 1957; Long, 1953, 1955, 1959) and food (Novák, 1960, 1974, Cayrol, 1962;). The widely polyphagous larvae may eat the leaves of more than 200 host plant species (Schwitulla, 1963). The preferred food plants change with the course of the season as a consequence of host plant senescence (Novák, 1960, 1974; Steudel, 1963). In addition to the wide range of natural host plants, under laboratory conditions the larvae eat many plant species not accepted in the open. The food induced plasticity of development rate provides an opportunity for studying the variation of thermal constants. By looking at parallels in variation of growth rate and food assimilation under different temperatures, we may determine the causes of variation in SET.

In our experiments we tested the hypothesis of "rate isomorphy" in A. gamma larvae provided with leaves of several host plant species. Development time, pupal mass, and food assimilation were studied at 3 experimental temperatures. The data enabled (1) the determination of the thermal constants of larval development, (2) testing for "rate isomorphy", (3) the establishment of variation in body growth under different trophic conditions and (4) calculations of the relationship between food assimilation and larval development.

\section{MATERIAL AND METHODS}

Rearing of larvae. Adult $A$. gamma moths were collected at Prague Ruzyně $\left(50^{\circ} 06^{\prime} \mathrm{N}, 14^{\circ} 15^{\prime} \mathrm{E}\right)$, in August, 1988 . The moths flying in an alfalfa stand were captured by use of entomology net when feeding on flowers. Groups of three female and three male moths were placed into cardboard cylinders of $15 \mathrm{~cm}$ diameter and $15 \mathrm{~cm}$ height covered by a glass lid and provided with a diluted commercial mixed fruit syrup. This source of water and carbohydrates was offered in a petri dish $(7 \mathrm{~cm}$ diam.) covered with a thin stiff nylon fabric (1.5 mm mesh size) which prevented the moths from drowning. Eggs were laid overnight, on the side-walls of the cylinder. Each day the moths were moved to a new cylinder, the pieces of cardboard with groups of eggs were cut out and until hatching placed into $3.5 \times 12 \mathrm{~cm}$ glass tubes covered with dense nylon fabric. The freshly hatched larvae were removed at $24 \mathrm{~h}$ intervals and used for experiments. Adults and eggs were placed until hatching at room temperature $\left(25 \pm 1^{\circ} \mathrm{C}\right)$ and natural photoperiod.

Food. Experimental larvae were supplied with fresh leaves picked from the plants growing in the open. Thirteen plant species (Dostál, 1989) covering the range of preferred and nonpreferred hosts were selected: Amaranthus retroflexus L. (Amaranthaceae), Pastinaca sativa L. (Apiaceae), Achillea millefolium L., Cirsium arvense (L.) Scop., Matricaria maritima L., Taraxacum officinale Weber in Wiggers (Asteraceae), Sambucus nigra L. (Caprifoliaceae), Medicago sativa L., Robinia pseudoacacia L. (Fabaceae), Geranium pratense L. (Geraniaceae), Plantago major L. (Plantaginaceae), Salix babylonica L.
(Salicaceae), Urtica dioica L. (Urticaceae). Experiments were made in August (development duration) and September 1988 (food assimilation). Water and total nitrogen content of leaves were measured in early September. For each host plant species c. $200 \mathrm{~g}$ of fresh leaves were weighed and dried to a constant mass at $90^{\circ} \mathrm{C}$. The dry mass and nitrogen content of each sample was then determined and the water content of the fresh leaves calculated. The determination of $\mathrm{N}$ content was made commercially, by a laboratory using a standard (Kjeldahl) method.

Development time and pupal mass. Cohorts of $0-24 \mathrm{~h}$ old larvae hatched at room conditions were transferred to constant temperatures of $15.0,20.3$ and $26.7^{\circ} \mathrm{C}$ and $18 \mathrm{~L}: 6 \mathrm{D}$ photoperiod where the larvae were kept in $3.5 \times 12 \mathrm{~cm}$ glass tubes covered with dense nylon fabric. First and second instar larvae were reared in groups of 20, and at the end of the 2 nd instar the larvae were placed in individual tubes and then kept alone until pupation. The larvae were provided with leaves of the 13 host plant species mentioned above. Fresh leaves were supplied and faeces removed every 2 or 3 (weekends) days. Pupation was observed daily, at 07:00 and 19:00. The pupae were sexed and their live body mass was established within $24 \mathrm{~h}$ from pupation, with an accuracy of $0.1 \mathrm{mg}$. Ten randomly selected pupae were killed, dried to constant mass and their dry matter content was determined.

Food utilization. The cohorts of $0-24 \mathrm{~h}$ old larvae hatched at room conditions were isolated. The larvae were then kept in 500 $\mathrm{ml}$ glass cylindric vials covered with dense nylon fabric. Until the 4th instar the larvae were reared in groups of 15-20 per vial, kept at room conditions $\left(25 \pm 1^{\circ} \mathrm{C}\right.$, natural photoperiod) and in 2 or $3 \mathrm{~d}$ (weekends) intervals supplied with fresh $T$. officinale leaves. The larvae of early 4th instar were removed from food and starved for $24 \mathrm{~h}$ to empty the gut contents. The larvae were then divided into groups of 5 randomly selected individuals and the groups of larvae were weighed. Each group was then placed into a $500 \mathrm{ml}$ vial and supplied with a weighed quantity of fresh leaves. The leaves were collected within $4 \mathrm{~h}$ of establishing the experiment and maintained in plastic sacks to prevent desiccation during handling. Dry matter content of these leaves was determined in 5 samples randomly selected from the leaf supply of each plant species. The vials with larvae and food were then put in constant temperatures of $15.0,20.3$ and $26.7^{\circ} \mathrm{C}$ and $18 \mathrm{~L}$ : $6 \mathrm{D}$ photoperiod. The larvae were allowed to feed on the leaves for $2 \mathrm{~d}$ (at $\left.26.7^{\circ} \mathrm{C}\right), 3 \mathrm{~d}\left(20.3^{\circ} \mathrm{C}\right)$ or $5 \mathrm{~d}\left(15.0^{\circ} \mathrm{C}\right)$. At the end of this feeding period the larvae were removed from food, starved for $24 \mathrm{~h}$ and weighed. Dry matter content of the larval body was determined by weighing the fresh and dry mass of 10 randomly selected larvae. For each group, the remaining non-consumed leaves (food) and faeces produced during feeding and postfeeding starvation period were collected, dried to constant weight and weighed.

Data elaboration. In each temperature $\mathrm{T}$, larval development length $\mathrm{D}$ was measured as number of days elapsed from the egg hatching (isolation of the 1st instar larvae cohort) until larvalpupal ecdysis. Development rate $\mathrm{R}$ was calculated as $\mathrm{D}^{-1}$. The regression $\mathrm{R}=\mathrm{a}+\mathrm{b} \times \mathrm{T}$ (where $\mathrm{a}$ and $\mathrm{b}$ are constants) was calculated. From here lower development threshold $\left({ }^{\circ} \mathrm{C}\right)$ was calculated as $\mathrm{LDT}=-\mathrm{b} \times \mathrm{a}^{-1}$ and sum of effective temperatures (day degrees $\mathrm{dd}$ ) as SET $=\mathrm{b}^{-1}$. Standard deviations of LDT were calculated according to Janáček et. al (in litt.). Multiple regression of SET on water and N content was calculated using Statistica ${ }^{\circledR}$ (StatSoft, 1994). High SET for poor diets that had been calculated from only 2 temperatures were included because they increased the significance of the regression. The mass of neonate larvae was below the limits of weighing precision and thus negligible compared to pupal mass PM. The growth rate GR 


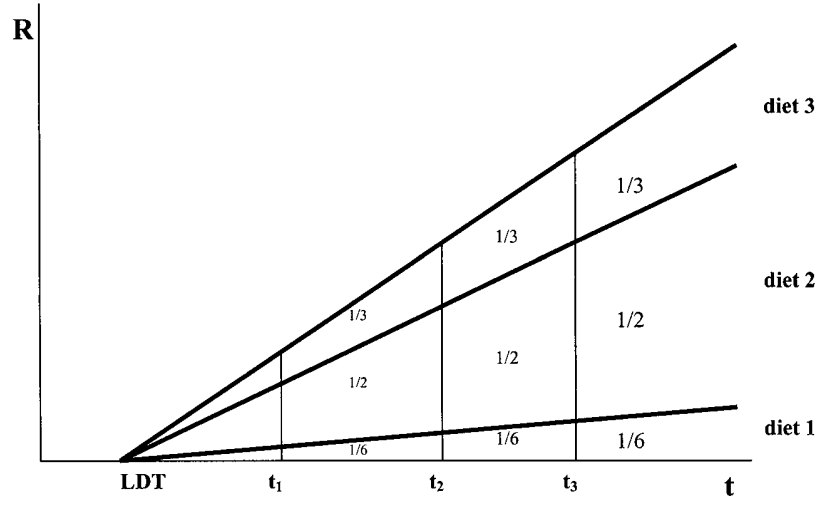

Fig. 1. An illustration of the effect of temperature (t) and three different diets on rate of development $(R)$ of larvae within the linear range of the relationship between $\mathrm{R}$ and $\mathrm{t}$. The larvae are isomorphic, and at each temperature $\left(t_{1}, t_{2}, t_{3}\right), 1 / 6$ of the total time spent on the three diets is spent on diet $1,1 / 2$ on diet 2 , and $1 / 3$ on diet 3 . Larvae on all three diets have a common lower developmental threshold (LDT).

average body mass increment per day) was therefore calculated as $\mathrm{GR}=\mathrm{PM} \times \mathrm{D}^{-1}$. Standardized growth rate SGR (average body mass increment per day degree) was calculated as $\mathrm{SGR}=\mathrm{PM} \times \mathrm{SET}^{-1}$. SGR compensated for differences in growth rate caused by temperature and revealed the variation caused by food. In food utilization experiments, dry mass of ingested food (F), dry mass of excrement (E) and dry body mass increments (I) were calculated. These values were used to calculate the indices of food assimilation, efficiency of food conversion $\mathrm{ECI}=\mathrm{I} \times \mathrm{F}^{-1}$ and metabolic efficiency $\mathrm{ECD}=\mathrm{I} \times(\mathrm{F}-\mathrm{E})^{-1}$. Relative growth rate was calculated as $\mathrm{RGR}=\exp \left((\ln \mathrm{Wf}-\ln \mathrm{Wi}) \times \mathrm{d}^{-1}\right) \times \mathrm{Wi}^{-1}$ where $\mathrm{Wi}$ is initial mass and Wf final mass of an individual larva in the feeding experiment, and $\mathrm{d}$ is duration of the experiment (days) (Barbehenn et al., 1999). Means are accompanied by \pm SE throughout the paper.

Testing for "rate isomorphy". Rate isomorphy implies no change in the proportion of time spent on a particular diet with

TABLE 1. Number of pupated individuals $(\mathrm{N})$, per cent mortal larvae kept at 3 constant temperatures and fed with leaves of 13 host plant species.

\begin{tabular}{|c|c|c|c|c|c|c|c|c|c|c|c|c|}
\hline \multirow{3}{*}{ Host plant } & \multicolumn{12}{|c|}{ Temperature $\left({ }^{\circ} \mathrm{C}\right)$} \\
\hline & \multicolumn{4}{|c|}{15.0} & \multicolumn{4}{|c|}{20.3} & \multicolumn{4}{|c|}{26.7} \\
\hline & $\mathrm{N}$ & $\mathrm{M}$ & $\mathrm{D}$ & W & $\mathrm{N}$ & M & $\mathrm{D}$ & $\mathrm{W}$ & $\mathrm{N}$ & $\mathrm{M}$ & $\mathrm{D}$ & $\mathrm{W}$ \\
\hline A. millefolium & 6 & 67 & $36.3 \pm 1.2$ & $336 \pm 33$ & 6 & 67 & $18.3 \pm 0.2$ & $307 \pm 6$ & 13 & 28 & $11.8 \pm 0.2$ & $254 \pm 6$ \\
\hline A. retroflexus & 4 & 78 & $56.9 \pm 0.5$ & $86 a$ & 7 & 61 & $24.4 \pm 0.7$ & $227 \pm 4$ & 15 & 17 & $14.5 \pm 0.3$ & $187 \pm 7$ \\
\hline C. arvense & 8 & 56 & $34.2 \pm 0.4$ & $352 \pm 14$ & 5 & 72 & $19.4 \pm 0.2$ & $318 \pm 8$ & 9 & 50 & $10.7 \pm 0.2$ & $272 \pm 9$ \\
\hline G. pratense & 5 & 72 & $47.2 \pm 1.9$ & $258 \pm 28$ & 9 & 50 & $20.2 \pm 0.3$ & $324 \pm 4$ & 7 & 61 & $14.5 \pm 0.5$ & $249 \pm 7$ \\
\hline M. maritima & 0 & 100 & -- & -- & 9 & 50 & $23.8 \pm 0.4$ & $182 \pm 8$ & 6 & 67 & $14.8 \pm 0.9$ & $191 \pm 17$ \\
\hline M. sativa & 1 & 94 & 42.0 & 202 & 3 & 83 & $20.3 \pm 0.6$ & $226 \pm 15$ & 11 & 39 & $11.8 \pm 0.2$ & $183 \pm 10$ \\
\hline$P$. sativa & 4 & 78 & $41.9 \pm 2.6$ & $305 \pm 43$ & 3 & 83 & $16.9 \pm 0.1$ & $354 \pm 10$ & 6 & 67 & $11.7 \pm 0.2$ & $289 \pm 10$ \\
\hline P. major & 9 & 50 & $39.5 \pm 0.3$ & $350 \pm 15$ & 5 & 72 & $19.6 \pm 0.2$ & $339 \pm 7$ & 10 & 44 & $12.5 \pm 0.3$ & $287 \pm 7$ \\
\hline R. pseudoacacia & 0 & 100 & -- & -- & 0 & 100 & -- & -- & 3 & 83 & $27.5 \pm 0.9$ & $117 \pm 13$ \\
\hline S. babylonica & 1 & 94 & 64.9 & -- & 0 & 100 & -- & -- & 11 & 39 & $20.6 \pm 0.6$ & $195 \pm 11$ \\
\hline S. nigra & 0 & 100 & -- & -- & 0 & 100 & -- & -- & 10 & 44 & $14.1 \pm 0.3$ & $227 \pm 9$ \\
\hline T. officinale & 11 & 39 & $36.4 \pm 1.0$ & $375 \pm 9$ & 24 & 4 & $17.4 \pm 0.1$ & $335 \pm 4$ & 8 & 56 & $10.3 \pm 0.2$ & $284 \pm 8$ \\
\hline U. dioica & 13 & 28 & $35.6 \pm 0.4$ & $362 \pm 6$ & 20 & 20 & $18.7 \pm 0.2$ & $329 \pm 4$ & 15 & 17 & $11.2 \pm 0.1$ & $265 \pm 5$ \\
\hline
\end{tabular}

change in temperature (Fig. 1). Therefore, within the range of the linear relationship between development rate $R$ and temperature $t$, the consequence of rate isomorphy is common $L D T$ for larvae on all diets, in spite of different development rates on each diet. The prediction of rate isomorphy, namely uniform LDT accompanied by proportional variation of SET, was tested by designating the arcsin $\sqrt{\text { proportion }}$ of the time spent on particular diet as the response variable, and temperature and diet as factors. The data were analysed by two-way ANOVA with temperature and diet as fixed effects. The existence of rate isomorphy was inferred from a zero change in the development time proportion at changing temperature, and the existence of variation in SET from differences in the development time proportions on individual diets. A zero change in the development time proportion at different temperature accompanied by differences in the proportions on individual diets indicated rate isomorphy. Different development time proportions on individual diets accompanied by variation in the proportions at different temperatures violated the assumptions of rate isomorphy.

\section{RESULTS}

Thermal constants of development. The duration of larval development decreased and development rate increased with increasing temperature (Tables 1 and 2). Mortality was generally high, and was not correlated with temperature or kind of food. This might be caused by diseases introduced to laboratory cultures by food contaminated in the open. Thermal constants were calculated for development on 11 host plant species of which 9 permitted complete larval development at 3 temperatures while with 2 host plant species development was completed at 2 temperatures. Experimental LDT for all species were similar $\left(9.3-11.0^{\circ} \mathrm{C}\right.$, average $9.9 \pm 0.2^{\circ} \mathrm{C}$ ) (Table 2). As development rate was largely affected by food, larvae fed with leaves of some host plant species extended their development time by up to 3 times compared that found with optimum food. Consequently, the variation in SET was large and the slow growing larvae

ty (M), larval development time (D) and fresh pupal mass (W) of Temperature $\left({ }^{\circ} \mathrm{C}\right)$ 


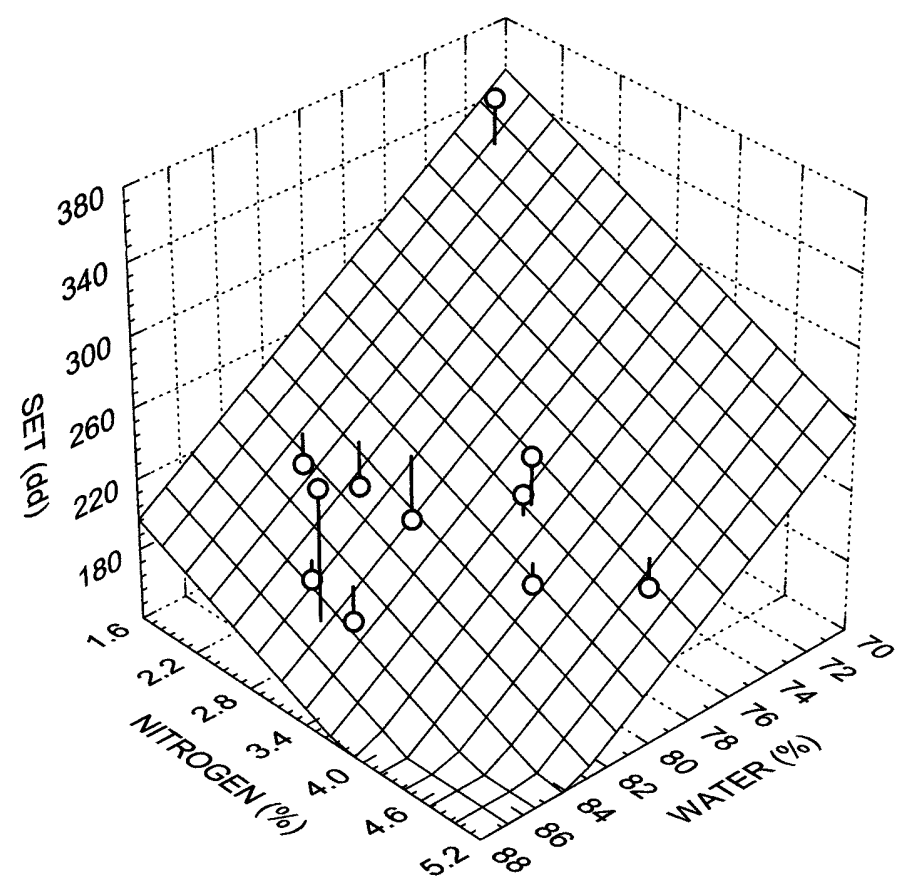

Fig. 2. The influence of food quality, the water content $\left(\mathrm{t}_{(8)}=-3.034, \mathrm{p}=0.016\right)$ and $\mathrm{N}$ content $\left(\mathrm{t}_{(8)}=-1.957, \mathrm{p}=0.086\right)$ of host plant leaves on SET of the larval development $\left(\mathrm{R}^{2}=0.614, \mathrm{~F}_{(2,8)}=6.367, \mathrm{p}=0.022\right)$. Data for each host plant is represented by one point.

fed with $S$. babylonica leaves had 2.3 times greater SET (353 dd) than larvae fed with T. officinale $(167 \mathrm{dd})$ (Table 2).

Rate isomorphy. Proportion of the total development time spent on a particular diet significantly interacted with temperature and type of $\operatorname{diet}(\mathrm{ANOVA}: \mathrm{F}=9.236$; $\mathrm{df}$ $=16,225 ; \mathrm{p}<0.001)$. At particular temperatures, the proportion significantly varied with diet (Table 3 ). This confirms that the SET is very plastic and changes with food quality. The proportion did not significantly vary with temperature for larvae reared on Medicago sativa, Pastinaca sativa and Taraxacum officinale (Table 4). It means that on these diets, the variation of SET is proportional with changing temperature. The larvae fed by these diets have a common LDT and their development is thus isomorphic. The development time proportion varied with temperature on other diets. Larval development thus violated rate isomorphy. However, the variation in larval development time on particular diets at different temperatures (Table 4) was much less than the variation on different diets at any given temperature (Table 3). The violation of rate isomorphy thus appeared to be generally negligible and the differences in LDT for larvae reared on different diets were small compared to differences in SET

TABLE 2. Food quality as indicated by per cent water (WC) and total N content (NC) in leaves, regression constants a, b (development rate $=\mathrm{a} \times$ temperature $+\mathrm{b})$, thermal constants SET $(\mathrm{dd})$ and LDT $\left({ }^{\circ} \mathrm{C}\right)$ calculated from experimental data, and SET recalculated under assumption of "rate isomorphy" principle $\left(\mathrm{SET}_{\mathrm{rec}}\right)$.

\begin{tabular}{|c|c|c|c|c|c|c|c|}
\hline Host plant & WC & $\mathrm{NC}$ & $\mathrm{a}\left(\times 10^{3}\right)$ & $\mathrm{b}\left(\times 10^{2}\right)$ & LDT & SET & $\mathrm{SET}_{\text {rec }}$ \\
\hline A. millefolium & 81.4 & 2.50 & 4.886 & -4.535 & $9.3 \pm 0.2$ & 205 & 188 \\
\hline A. retroflexus & 79.2 & 3.75 & 4.397 & -4.833 & $11.0 \pm 0$ & 227 & 257 \\
\hline C. arvense & 84.9 & 2.77 & 5.509 & -5.587 & $10.1 \pm 0.8$ & 182 & 182 \\
\hline G. pratense & 78.8 & 3.75 & 4.060 & -3.729 & $9.2 \pm 1.2$ & 246 & 227 \\
\hline M. maritima & 85.9 & 3.54 & 4.000 & -3.915 & 9.8 & 250 & \\
\hline$M$. sativa & 77.3 & 4.64 & 5.216 & -5.516 & $10.6 \pm 0.3$ & 192 & 205 \\
\hline$P$ sativa & 80.5 & 2.86 & 5.201 & -5.149 & $9.9 \pm 0.9$ & 192 & 192 \\
\hline P. major & 82.5 & 2.14 & 4.688 & -4.471 & $9.5 \pm 0.1$ & 213 & 202 \\
\hline R. pseudoacacia & 68.8 & 3.17 & & & & & \\
\hline S. babylonica & 71.9 & 2.16 & 2.833 & -2.709 & 9.6 & 353 & \\
\hline S. nigra & 82.1 & 3.57 & & & & & \\
\hline T. officinale & 84.5 & 3.12 & 5.995 & -6.308 & $10.5 \pm 0.2$ & 167 & 177 \\
\hline U. dioica & 80.0 & 4.02 & 5.250 & -5.154 & $9.8 \pm 0.3$ & 190 & 185 \\
\hline Average & & & & & $9.9 \pm 0.2$ & $219.7 \pm 14.7$ & $201.7 \pm 7.3$ \\
\hline
\end{tabular}



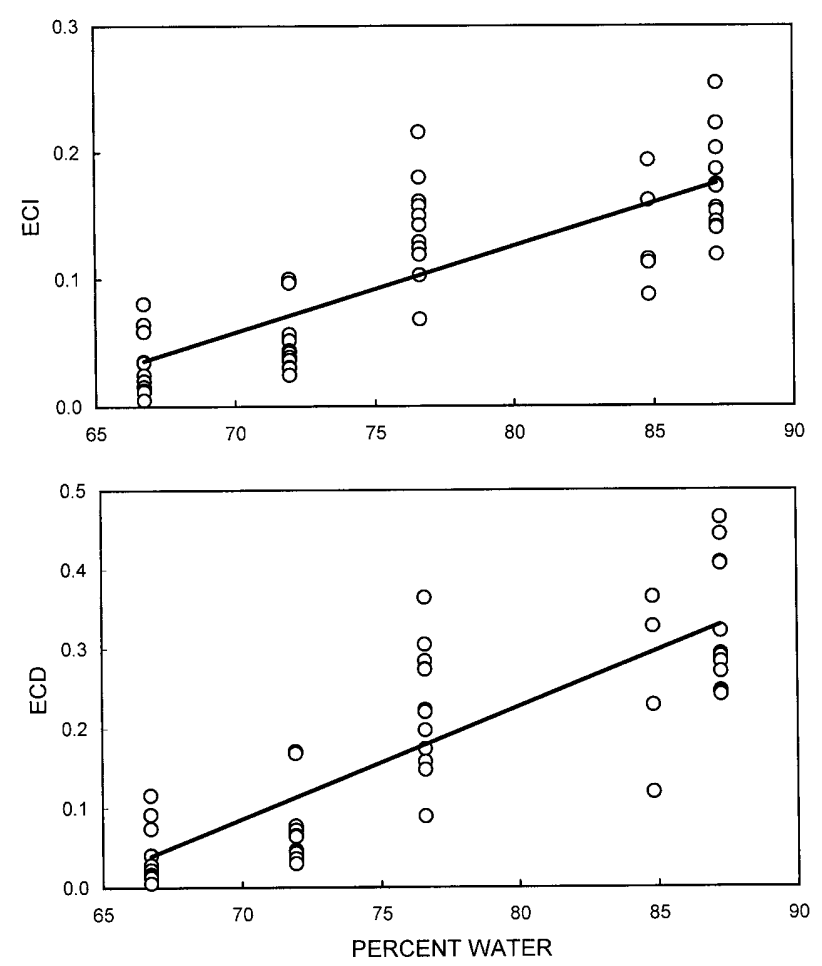

Fig. 3. Proportion of water content (W) in the food in relation to efficiency of food conversion $\left(\mathrm{ECI}=0.0068 \mathrm{~W}-0.4514, \mathrm{R}^{2}=\right.$ $0.645, \mathrm{p}<0.001)$ and metabolic efficiency $(\mathrm{ECD}=-0.0141 \mathrm{~W}-$ $\left.0.9047, \mathrm{R}^{2}=0.694, \mathrm{p}<0.001\right)$. Each point represents an experiment replicate, a group of 5 larvae.

(Table 2). The data for 9 diets where development rate was established in 3 experimental temperatures were recalculated assuming rate isomorphy. The recalculated LDT was $10.0^{\circ} \mathrm{C}$ (identical with the average LDT calculated as the arithmetical mean of the experimental data for these foods). The recalculated SET $_{\text {rec }}$ differed by up to 30 dd from SET calculated from experimental data (Table 2).

Effect of food quality. The SET increased with decreasing water content and decreasing nitrogen content of food (Fig. 2). Multiple regression analysis indicated a significant contribution of variation in food dry matter content $\left(\mathrm{t}_{(8)}=3.152, \mathrm{p}=0.014\right)$ while the effect of nitrogen content was below the limit of statistical significance $\left(\mathrm{t}_{(8)}=-2.011, \mathrm{p}=0.079\right)$. The increase of SET was paralleled by decreasing efficiency of food assimilation

TABLE 3. ANOVA of the proportion (angular transformation) of the total development time spent on different diets at 15 , 20.3 and $26.7^{\circ} \mathrm{C}$.

\begin{tabular}{llcclcc}
\hline $\begin{array}{l}\text { Tem- } \\
\text { pera- } \\
\text { ture } \\
\left({ }^{\circ} \mathrm{C}\right)\end{array}$ & $\begin{array}{l}\text { Source of } \\
\text { variation }\end{array}$ & Df & SS & MS & F & P \\
\hline 15 & Among diets & 8 & 0.0365 & 0.00456 & 37.02 & $<0.001$ \\
& Within diets & 51 & 0.00629 & 0.000123 & & \\
20.3 & Among diets & 8 & 0.0237 & 0.00296 & $63.49<0.001$ \\
& Within diets & 73 & 0.00341 & 0.0000467 & & \\
26.7 & Among diets & 8 & 0.0382 & 0.00477 & $309.70<0.001$ \\
& Within diets & 85 & 0.0105 & 0.000123 & & \\
\hline
\end{tabular}
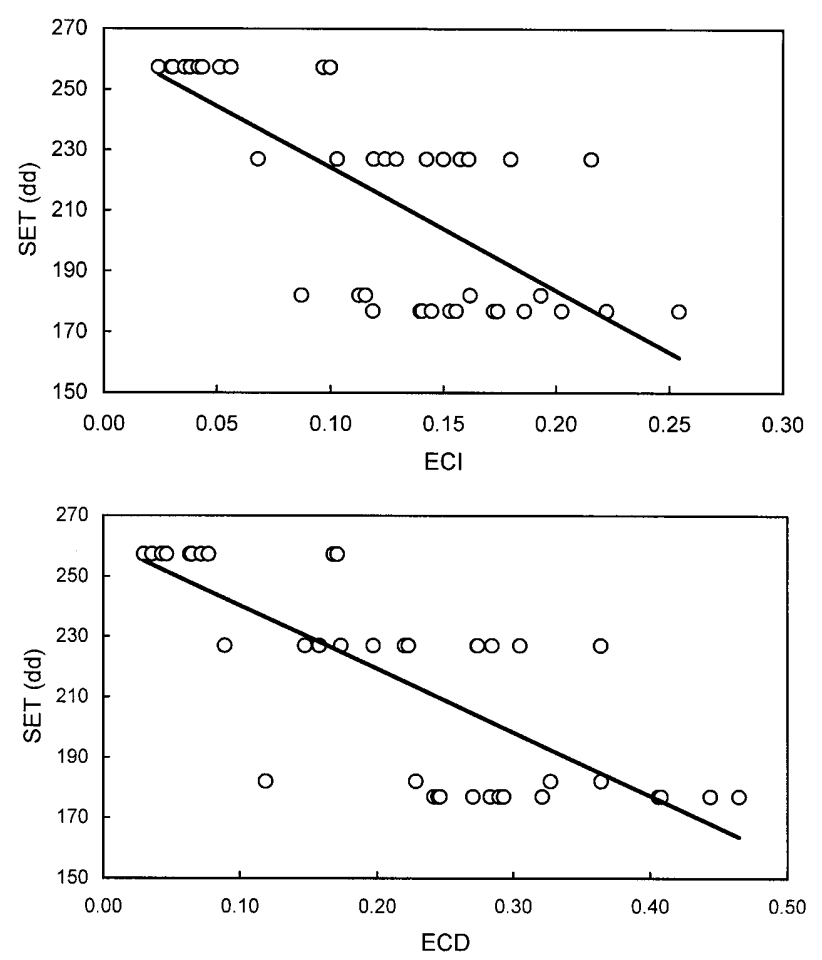

Fig. 4. Sum of effective temperatures SET for development of larvae on 4 host plants (from above: A. retroflexus, G. pratense, C. arvense and T. officinale) in relation to the efficiency of food conversion ECI $\left(\mathrm{SET}=-406.3 \mathrm{ECI}+264.8, \mathrm{R}^{2}=0.515, \mathrm{p}<\right.$ $0.001)$ and metabolic efficiency ECD (SET $=-210.4 \mathrm{ECD}+$ 261.4, $\mathrm{R}^{2}=0.584, \mathrm{p}<0.001$ ). Meaning of points as in Fig. 3 .

which also was largely determined by food quality. ECD and ECI (Fig. 3) decreased with decreasing water content in food. SET established on 4 host plants were consequently significantly correlated with ECI and ECD (Fig. 4). Food ingestion and RGR were also negatively influenced by decreasing water content of the food and RGR significantly increased with ECD and ECI (Fig. 5). By contrast, the effect of temperature on larval metabolism was not significant when data were pooled across foods. Food consumption, growth rate, as well as metabolic efficiency ECD and efficiency of food conversion ECI (Fig. 6) did not significantly change with temperature.

Body growth. Pupal mass increased with temperature and, within each temperature, decreased with the length of development time (Fig. 7). Pupal mass was thus determined by growth rate GR which significantly increased with temperature (Fig. 8). Recalculation of data to SGR which removed the effect of temperature revealed that pupal mass increased with SGR and the increase was typical for particular food types (Fig. 8). The increasing SET was inversely proportional to decreasing SGR (Fig. 9).

\section{DISCUSSION}

Constraints on LDT. The prediction of uniform LDT derived from the assumption of rate isomorphy (RI) was confirmed only on 3 from 9 diets where development was completed in all temperatures. It is not surprising because we had available only 3 experimental temperatures. Even 

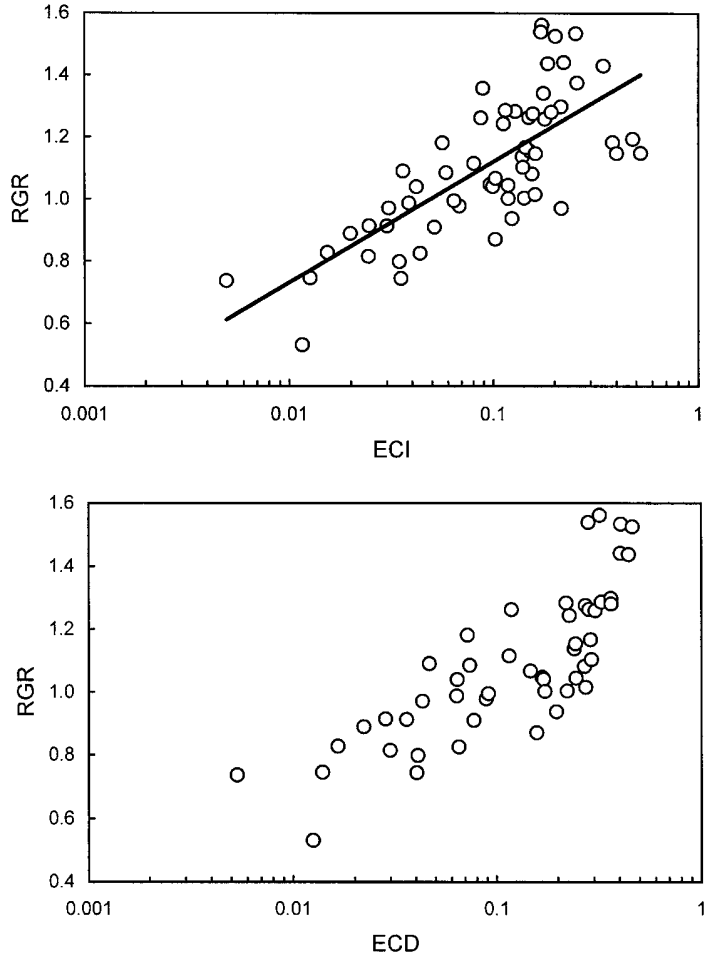

Fig. 5. Relative growth rate RGR (mg. $\left.\mathrm{mg}^{-1} \cdot \mathrm{d}^{-1}\right)$ in relation to efficiency of food conversion ECI $(\mathrm{RGR}=0.1691 \mathrm{nECI}+1.509$, $\left.\mathrm{R}^{2}=0.539, \mathrm{p}<0.001\right)$ and metabolic efficiency. The significance of the RGR vs. ECD relationship was not tested because of autocorrelation. Meaning of points as in Fig. 3.

if LDTs are calculated from data collected over a range of ecologically relevant temperatures, and the regression of development rate on temperature is linear, the accuracy of the estimates is affected by errors in the estimates of the
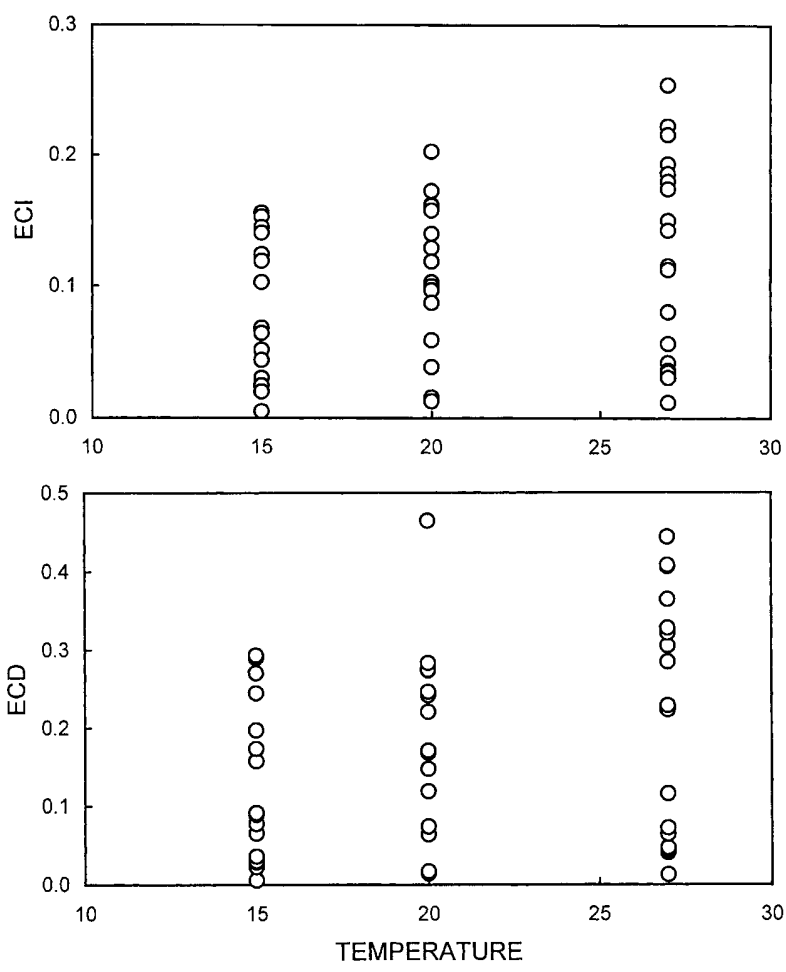

Fig. 6. Efficiency of food conversion ECI $\left(\mathrm{R}^{2}=0.060, \mathrm{p}>\right.$ $0.05)$ and metabolic efficiency $\operatorname{ECD}\left(\mathrm{R}^{2}=0.034, \mathrm{p}>0.05\right)$ in relation to temperature $\left({ }^{\circ} \mathrm{C}\right)$. Meaning of points as in Fig. 3 .

development rate (Campbell et al., 1974). The low precision of LDTs is obvious from their large standard errors (Table 2).

The largest departure from expected proportions assuming the existence of rate isomorphy is at the lowest

TABLE 4. ANOVA of the proportion (angular transformation) of the total development time spent at different temperatures on individual diets.

\begin{tabular}{|c|c|c|c|c|c|c|}
\hline Diet & Source of variation & Df & SS & MS & $\mathrm{F}$ & $\mathrm{P}$ \\
\hline \multirow[t]{2}{*}{ Achillea millefolium } & Among temperatures & 2 & 0.00119 & 0.000596 & 6.746 & 0.005 \\
\hline & Within temperatures & 22 & 0.00194 & 0.0000883 & & \\
\hline \multirow[t]{2}{*}{ Amaranthus retroflexus } & Among temperatures & 2 & 0.00282 & 0.00141 & 8.189 & 0.002 \\
\hline & Within temperatures & 23 & 0.00396 & 0.000172 & & \\
\hline \multirow[t]{2}{*}{ Cirsium arvense } & Among temperatures & 2 & 0.00290 & 0.00145 & 22.15 & $<0.001$ \\
\hline & Within temperatures & 19 & 0.00124 & 0.0000654 & & \\
\hline \multirow[t]{2}{*}{ Geranium pratense } & Among temperatures & 2 & 0.00299 & 0.00150 & 8.279 & 0.003 \\
\hline & Within temperatures & 18 & 0.00325 & 0.000181 & & \\
\hline \multirow[t]{2}{*}{ Medicago sativa } & Among temperatures & 2 & 0.000344 & 0.000172 & 2.639 & 0.11 \\
\hline & Within temperatures & 12 & 0.000782 & 0.0000651 & & \\
\hline \multirow[t]{2}{*}{ Plantago major } & Among temperatures & 2 & 0.000714 & 0.000357 & 3.841 & 0.04 \\
\hline & Within temperatures & 21 & 0.00195 & 0.0000929 & & \\
\hline \multirow[t]{2}{*}{ Pastinaca sativa } & Among temperatures & 2 & 0.00126 & 0.00063 & 3.68 & 0.06 \\
\hline & Within temperatures & 10 & 0.00171 & 0.000171 & & \\
\hline \multirow[t]{2}{*}{ Taraxacum officinale } & Among temperatures & 2 & 0.000473 & 0.000236 & 3.075 & 0.06 \\
\hline & Within temperatures & 39 & 0.00300 & 0.0000770 & & \\
\hline \multirow[t]{2}{*}{ Urtica dioica } & Among temperatures & 2 & 0.00249 & 0.00124 & 23.95 & $<0.001$ \\
\hline & Within temperatures & 45 & 0.00234 & 0.0000520 & & \\
\hline
\end{tabular}




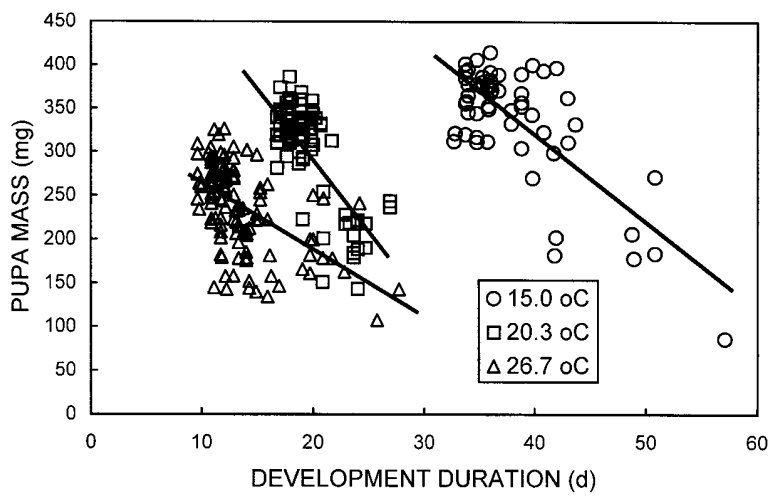

Fig. 7. The relationship between pupal mass and development duration at different temperatures. $15^{\circ} \mathrm{C}$ : pupal mass $=0.71-$ 0.0098 development duration; $20.3^{\circ} \mathrm{C}$ : pupal mass $=0.63-$ 0.017 development duration; $26.7^{\circ} \mathrm{C}$ : pupal mass $=0.34-$ 0.0077 development duration. $\mathrm{F}=100.4 ; \mathrm{df}=5,262 ; \mathrm{p}<<$ $0.001 ; \mathrm{R}^{2}=65.7 \%$. Each point represents 1 individual.

or the highest temperatures (Jarošík et al., in prep.). There are three reasons why these temperatures may violate rate isomorphy. At low temperature there may be differential mortality. The individuals with the fastest development complete their development early while the rest succumb to adverse conditions, the more so if their development is prolonged. The second reason is an imprecise measuring of developmental time at high temperatures. As developmental time decreases with temperature, the number of observations per stage also decreases if monitoring is made at constant intervals at low and high temperatures. The third reason is crucial from a statistical point of view. An important determinant of the slopes of the linear regressions, from which the LDTs are inferred, are the highest and the lowest values (see Crawley 1993, p. 78-82). Therefore, a relatively small bias in the developmental rates measured at the highest or the lowest temperatures will cause a large shift in the LDT.

The common LDT for $A$. gamma larvae calculated using data for 11 host plant species was $9.9 \pm 0.2^{\circ} \mathrm{C}$, by $2.3^{\circ} \mathrm{C}$ higher than the LDT calculated for a UK popula-

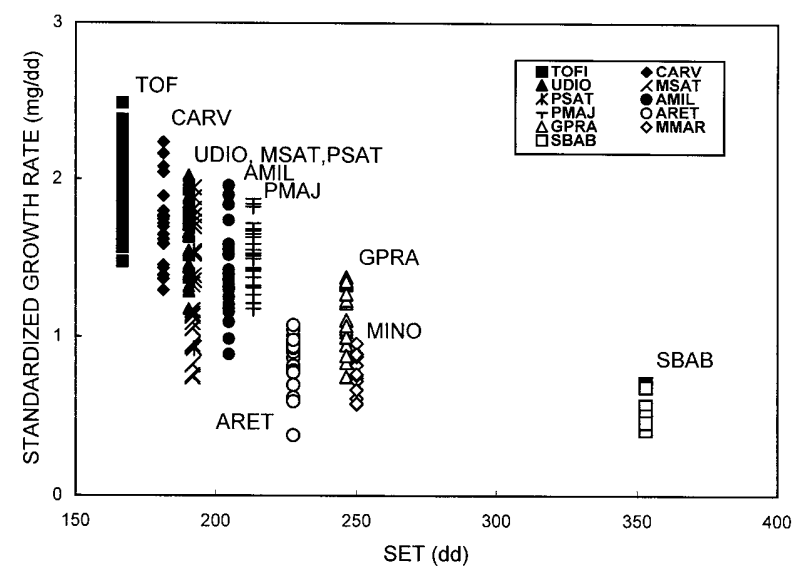

Fig. 9. Standardized growth rate $(\mathrm{mg} / \mathrm{dd})$ in relation to SET for different host plants (data pooled over temperatures). Regression for average value for each host plant: growth rate $=$ $2.9-0.0073$ SET. $F=16.80 ; \mathrm{df}=1,9 ; \mathrm{p}<0.003 ; \mathrm{R}^{2}=65.1 \%$. Acronyms as in Fig. 8, meaning of points as in Fig. 7.
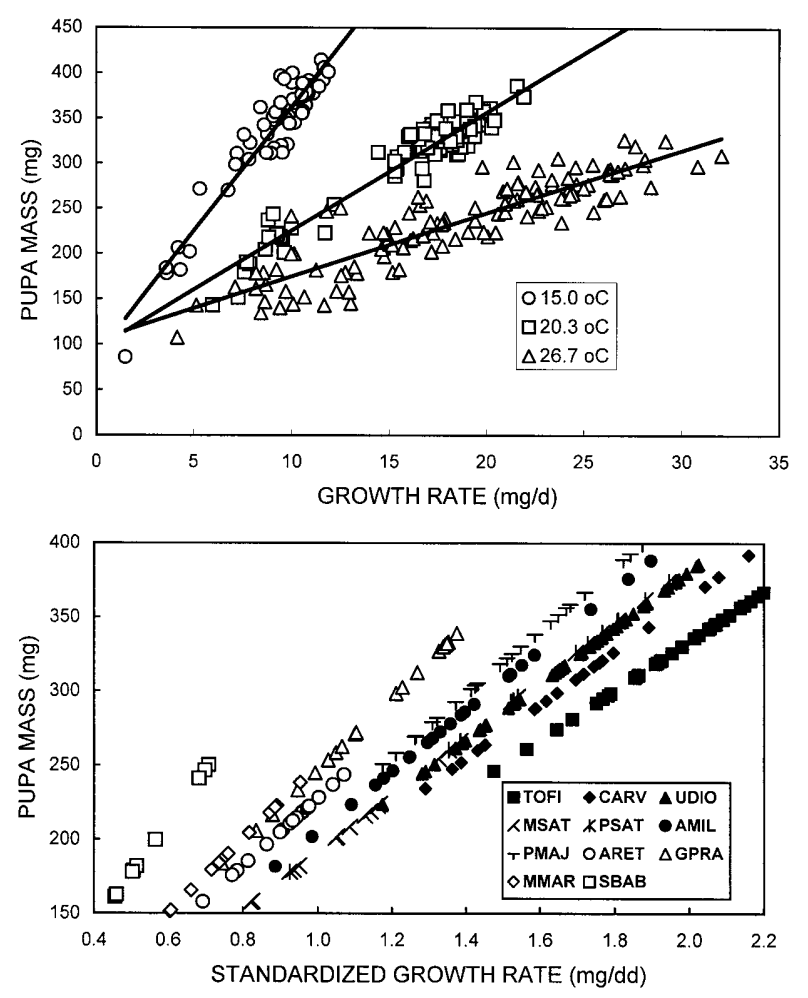

Fig. 8. Above: The relationship between pupal mass and growth rate $(\mathrm{GR})$ at different temperatures. $15^{\circ} \mathrm{C}$ : pupal mass $=$ $99.2+25.9 \mathrm{GR} ; 20.3^{\circ} \mathrm{C}$ : pupal mass $=99.2+12.8 \mathrm{GR} ; 26.7^{\circ} \mathrm{C}$ : pupal mass $=99.2+7.3 \mathrm{GR} . \mathrm{F}=889.3 ; \mathrm{df}=3,264 ; \mathrm{p}<<0.001$; $\mathrm{R}^{2}=91.0 \%$. Below: The relationship between pupal mass and standardized growth rate SGR (pooled over temperatures) at different host plants. $F=22.1 ; \mathrm{df}=21,234 ; \mathrm{p} \ll 0.001 ; \mathrm{R}^{2}=$ $66.5 \%$. Increase in pupal mass is host-plant specific $(\mathrm{F}=2.982$; $\mathrm{df}=11,245 ; \mathrm{p}<0.001)$. TOFI $-\mathrm{T}$. officinale, MSAT $-M$. sativa, PMAJ $-P$. major, MMAR $-M$. maritima, CARV $-C$. arvense, $\mathrm{PSAT}-P$. sativa, ARET $-A$. retroflexus, $\mathrm{SBAB}-S$. babylonica, UDIO - U. dioica, AMIL - A. millefolium, GPRA G. pratense. Meaning of points as in Fig. 7.

tion of this species (Hill \& Gatehouse, 1992) which was $7.7^{\circ} \mathrm{C}$ (male) and $7.6^{\circ} \mathrm{C}$ (female) (Table 5). The difference, tested using SD calculated for the UK data (Janáček et al., in litt.), was not significant $\left(\mathrm{t}_{2,4}=1.434, \mathrm{p}>0.05\right)$. In fact it is smaller than variation observed between populations of other species studied by more than one author, e.g. Heliothis armigera (Hübner) (LDT between 8.6$\left.12.9^{\circ} \mathrm{C}\right)$, Heliothis virescens $\left(\mathrm{F}\right.$.) $\left(7.6-11.8^{\circ} \mathrm{C}\right)$, or Trichoplusia ni (Hübner) $\left(9.0-14.7^{\circ} \mathrm{C}\right.$ ) (Table 5). The difference was apparently caused by variation of methods used in the two studies. Data on variation of LDT between populations were available for 12 noctuid species (Table 5). If we exclude the outlier data for populations of $A$. ipsilon (Hufnagel), Pseudaletia unipuncta (Haworth) and Spodoptera frugiperda (Smith) because of the large extent of variation in the differences between local populations, which were in the order of $1.7-5.7^{\circ} \mathrm{C}$ (mean $=3.9$ $\pm 0.4^{\circ} \mathrm{C}$ ). In general differences between the studies of different authors were greater than the differences "within" the studies.

Dixon et al. (1997) extended the idea of rate isomorphy (existence of a LDT constraint) to higher taxonomic 
TABLE 5. Thermal constants for larval development in noctuid moths of temperate regions. Number of populations investigated in a study $(\mathrm{Pn})$, number of experimental temperatures where development length was determined $(\mathrm{N})$, range of experimental temperatures (Range), lower development threshold (LDT) and sum of effective temperatures (SET).

\begin{tabular}{|c|c|c|c|c|c|c|}
\hline & \multirow[t]{2}{*}{$\mathrm{Pn}$} & \multicolumn{2}{|c|}{ Temperature $\left({ }^{\circ} \mathrm{C}\right)$} & \multirow[t]{2}{*}{$\operatorname{LDT}\left({ }^{\circ} \mathrm{C}\right)$} & \multirow[t]{2}{*}{ SET (dd) } & \multirow[t]{2}{*}{ Reference } \\
\hline & & $\mathrm{N}$ & Range $\left({ }^{\circ} \mathrm{C}\right)$ & & & \\
\hline Agrotis fucosa Butler & 1 & 3 & $20-28$ & 13.4 & 273.1 & Hasegawa \& Chiba, 1969 \\
\hline \multirow[t]{5}{*}{ Agrotis ipsilon (Hufnagel) } & 1 & 3 & $13-27$ & 7.2 & 502.7 & Archer et al., 1980 \\
\hline & 2 & 2 & $20-25$ & $8.5-10.8$ & $601.4-720.5$ & Fahmy et al., 1973 \\
\hline & 1 & 6 & $18-28$ & 8.8 & 322.5 & Hasegawa \& Chiba, 1969 \\
\hline & 1 & 4 & $18.3-26.7$ & 11.0 & 322.5 & Luckmann et al., 1976 \\
\hline & 1 & 2 & $21-25$ & 16.8 & 143.8 & Poitout \& Bues, 1974 \\
\hline $\begin{array}{l}\text { Agrotis segetum (Denis et } \\
\text { Schiffermüller) }\end{array}$ & 7 & 2 & $20-25$ & $10.5-12.4$ & $397.7-738.5$ & Weismann \& Podmanická, 1971 \\
\hline Anticarsia gemmatalis (Hübner) & 1 & 2 & $21.1-26.7$ & 16.4 & 154 & Leppla et al., 1977 \\
\hline Autographa biloba (Stephens) & 2 & 2 & $20-25$ & $10.6-11.6$ & $211.8-231.2$ & Beach \& Todd, 1988 \\
\hline Autographa californica (Speyer) & 1 & 5 & $14-30$ & 11.5 & 189.6 & Miller et al., 1984 \\
\hline Autographa gamma (L.) & 2 & 5 & $13-25$ & $7.6-7.7$ & $281.3-281.8$ & Hill \& Gatehouse, 1992 \\
\hline Dargida procincta (Grote) & 1 & 2 & $15-27$ & 7.0 & 410.3 & Kamm, 1991 \\
\hline Eudocima salaminia (Cramer) & 1 & 4 & $15-27$ & 11.9 & 280.2 & Sands et al., 1991 \\
\hline \multirow[t]{5}{*}{ Heliothis armigera (Hübner) } & 1 & 2 & $21-25$ & 8.6 & 254.2 & Poitout \& Bues, 1974 \\
\hline & 1 & 3 & $20-30$ & 12.9 & 185.7 & Quareshi et al., 1999 \\
\hline & 1 & 3 & $20-30$ & 10.2 & 298.4 & Sharma \& Chaudhury, 1988 \\
\hline & 1 & 5 & $13.1-27.1$ & 11.8 & 235.7 & Twine, 1978 \\
\hline & 1 & 3 & $15-25$ & 9.0 & 267.1 & Wu et al., 1980 \\
\hline Heliothis subflexa (Guenée) & 1 & 6 & $15-27.5$ & 12.2 & 222.5 & Butler et al., 1979 \\
\hline \multirow[t]{3}{*}{ Heliothis virescens (F.) } & 1 & 6 & $15-27.5$ & 11.4 & 230.7 & Butler \& Hamilton, 1976 \\
\hline & 3 & 6 & $15-27.5$ & $11.1-11.8$ & $199.9-229$ & Butler et al., 1979 \\
\hline & 1 & 3 & $20-30$ & 7.6 & 405.7 & Nadgauda \& Pitre, 1983 \\
\hline \multirow[t]{2}{*}{ Heliothis zea (Boddie) } & 3 & 3 & $15.6-25$ & $8.0-11.8$ & $225.2-419.6$ & Butler, 1976 \\
\hline & 8 & 2 & $20-25$ & $7.0-12.7$ & $187.5-498.2$ & Wiseman \& Isenhour, 1989 \\
\hline Hydraecia immanis (Guenée) & 1 & 4 & $18-27$ & 4.7 & 779.7 & Giebink et al., 1985 \\
\hline Hydraecia micacea (Esper) & 1 & 4 & $18-27$ & 6.6 & 558.2 & Giebink et al., 1985 \\
\hline Leucania loreyi Dupont & 1 & 3 & $15-25$ & 8.9 & 432.6 & Hirai, 1975 \\
\hline \multirow[t]{2}{*}{ Leucania separata Walker } & 1 & 3 & $15-25$ & 7.3 & 409.9 & Hirai, 1975 \\
\hline & 1 & 3 & $15-25$ & 9.0 & 293.1 & Sinchaisri \& Sogawa, 1969 \\
\hline Mamestra brassicae (L.) & 1 & 2 & $21-25$ & 11.4 & 212.2 & Poitout \& Bues, 1974 \\
\hline \multirow[t]{2}{*}{ Mamestra configurata Walker } & 1 & 5 & $8-24$ & 4.7 & 434.4 & Bailey, 1976 \\
\hline & 1 & 2 & $21-25$ & 9.5 & 275.6 & Poitout \& Bues, 1974 \\
\hline Mythimna convecta (Walker) & 3 & 3 & $15-25$ & $5.8-6.2$ & $461.4-502.9$ & Smith, 1984 \\
\hline Orthosia hibisci (Guenée) & 1 & 8 & $7.5-25$ & 4.1 & 258.5 & Judd et al., 1994 \\
\hline Papaipema nebris (Guenée) & 1 & 5 & $12.8-23.9$ & 3.1 & 1480.8 & Levine, 1983 \\
\hline \multirow[t]{2}{*}{ Peridroma saucia (Hübner) } & 1 & 4 & $10-25$ & 3.7 & 471.9 & Shields, 1983 \\
\hline & 1 & 5 & $10-26.7$ & 6.6 & 384.3 & Simonet et al., 1981 \\
\hline Phlogophora meticulosa (L.) & 2 & 4 & $11-21$ & $3.6-4.2$ & $572.1-678.4$ & Bues \& Poitout, 1980 \\
\hline Plathypena scabra (F.) & 2 & 4 & $15.6-26.7$ & 6.2 & $376.2-401.5$ & Hammond et al., 1979 \\
\hline \multirow[t]{3}{*}{ Pseudaletia unipuncta (Haworth) } & 1 & 4 & $13-28$ & 7.7 & 368.3 & Guppy, 1969 \\
\hline & 1 & 2 & $21-25$ & 0 & 460.5 & Poitout \& Bues, 1974 \\
\hline & 1 & 2 & $18-23$ & 11.0 & 292.1 & Taylor \& Shields, 1990 \\
\hline Simyra henrici (Grote) & 3 & 3 & $18.3-23.9$ & $9.6-10.3$ & $454.5-548.6$ & Decker \& Maddox, 1971 \\
\hline \multirow[t]{3}{*}{ Spodoptera exigua (Hübner) } & 3 & 3 & $18-26$ & $11.4-13.1$ & $128.0-185.9$ & Ali \& Gaylor, 1992 \\
\hline & 1 & 4 & $15-25$ & 10.2 & 231.6 & Butler, 1966 \\
\hline & 1 & 2 & $21-25$ & 16.1 & 97.8 & Poitout \& Bues, 1974 \\
\hline
\end{tabular}


TABLE 5 (continued).

\begin{tabular}{llllccc}
\hline Spodoptera frugiperda (Smith) & 3 & & $17-33$ & $12.4-12.9$ & $192.3-270.7$ & Ali et al.,1990 \\
& 4 & 2 & $20-25$ & $5.5-8.8$ & $262.7-331.2$ & Combs \& Valerio, 1980 \\
& 5 & 2 & $25-30$ & $15.3-18.6$ & $180.6-240.8$ & Isenhour et al., 1985 \\
Spodoptera littoralis (Boisduval) & 1 & 2 & $20-22.5$ & 12.7 & 227.9 & Baker \& Miller, 1974 \\
& 3 & 2 & $25-30$ & $8.6-9.7$ & $280.0-305.8$ & Nasr et al., 1973 \\
& 1 & 2 & $21-25$ & 16.5 & 119.2 & Poitout \& Bues, 1974 \\
& 1 & 3 & $15-25$ & 11.7 & 236.8 & Sidibé \& Lauge, 1977 \\
Spodoptera litura (F.) & 1 & 2 & $26-30$ & 7.2 & 307.2 & Bilapate \& Thombre, 1979 \\
& 3 & 5 & $16-28$ & $10.8-12.9$ & $248.3-260.6$ & Miyashita,1971 \\
& 1 & 3 & $15-25$ & 11.5 & 252.1 & Rao et al., 1989 \\
Trichoplusia ni (Hübner) & 2 & 5 & $19-26$ & $12.0-14.7$ & $119.3-165.3$ & Butler et al., 1975 \\
& 1 & 4 & $15-26.7$ & 9 & 252.3 & Jackson et al., 1969 \\
Trichoplusia orichalcea (F.) & 1 & 3 & $16.6-27.7$ & 12.9 & 164.6 & Toba et al., 1973 \\
Uraba lugens (Walker) & 4 & 2 & $15-28$ & $8.0-11.3$ & $194.1-269.0$ & Cabello, 1988 \\
Average & 3 & 3 & $15-25$ & $11.5-13.2$ & $453-460$ & Allen \& Keller, 1991 \\
\hline
\end{tabular}

groups of similar biology. Noctuid moths may be considered in this respect because they have a similar larval biology. To compare the available data we compiled a review of 48 studies on larvae of noctuid species of the temperate zone (Table 5). The included species are all folivorous facultatively polyvoltine phytophagans. In fact, the average LDT for 108 populations of 34 species, 10.2 $\pm 0.3^{\circ} \mathrm{C}$, is surprisingly close to the average LDT of $A$. gamma established in this study. Thus, despite the enormous variation of the literature data the assumption of rate isomorphy for the family of Noctuidae could not be rejected.

Plasticity of SET. The time (or heat) requirements for completing development of a stage as reflected by variation of the SET are plastic. At the species level this variation parallels taxonomic differences between species, but also trophic specialization of the taxa and the differences in body size (Honěk, 1999). Within populations of some species there exist adaptive differences between the sexes in development time (Nylin et al., 1993). However, in many other species the importance of sex linked differences is small (Honěk, 1997). Probably the most important differences in SET are caused by variation of food quality (Slansky \& Scriber, 1985; Slansky, 1993). In this study the differences in food quality caused a 2.6 fold variation in the SET. The leaves of 13 host plant species differed in their water and nitrogen content, which both together explained $62.2 \%$ of the variance in SET. This indicates a small effect of secondary factors, leaf surface quality and allelochemicals, on food acceptability for $A$. gamma larvae. This is apparently consistent with the broad polyphagy of this species which should overcome the defence barriers of a wide range of plant species.

The water content of food is an important factor in food utilization by caterpillars (Slansky, 1993). Its importance has been demonstrated with natural foods (Scriber, 1977, 1979a), synthetic diets (Schmidt \& Reese, 1988) and with stored products of different humidity (Nawrot, 1979;
Hagstrum \& Milliken, 1988). The effects of water content on food digestibility and larval growth was also demonstrated in other insect orders (e.g. Merkel, 1977). The importance of water content of food $(47.2 \%$ of variance in SET explained) for larval performance of $A$. gamma thus parallels other polyphagous insect species. The nitrogen content of food explained only $19.3 \%$ of total variance in SET of $A$. gamma. Although $\mathrm{N}$ content is an important factor of food quality for Lepidoptera larvae (Scriber 1979b; Lindroth et al., 1991; Bauce et al., 1994; Soontiens \& Bink, 1997), its relative importance is apparently smaller than in sucking insects where nitrogen content of phloem or xylem sap may become a limiting factor of larval growth and adult reproductive performance (e.g. Honěk et al., 1998; Ponder et al., 2000).

Growth. As with other insects, temperature and development time influenced final size (pupal mass) of the larva. The effect of temperature on body size is unimodal, with a monotonic decrease of body size below and above the "optimum" temperature (e.g. David et al., 1994). The temperature where insects grow to largest body size is always below the optimum for development time and reproduction efficiency. In $A$. gamma this temperature is less than or equal to $15.0^{\circ} \mathrm{C}$, since the average pupal mass decreased over the range of experimental temperatures $\left(15.0-26.7^{\circ} \mathrm{C}\right)$. Within each temperature pupal size decreased with increasing development time. There was no trade-off between body size and development time which might be expected under optimum trophic conditions (Begon et al., 1990). Extended larval development accompanied by lower final mass was apparently associated with the inability to compensate for reduced food quality (Slansky, 1993). In fact, the indices of efficiency of food assimilation decreased in parallel with decreasing growth rate and pupal mass. The variation of pupal size thus may appear as a non-adaptive result elicited by an environmental constraint. However, if we consider a wide spectrum of situations that the organism may face in the 
open, decreasing body size might still be adaptive (Wiklund et al., 1991; Nylin \& Gotthard, 1998). Pupating at small size may be advantageous in areas with constrained thermal unit availabilty (Ayres \& Scriber, 1994; Scriber, 1996). The study of fitness consequences of body size variation in $A$. gamma remains to be studied.

ACKNOWLEDGEMENTS. We thank J. Mark Scriber of the Michigan State University (USA) for helpful comments, Anthony F. G. Dixon of the University of East Anglia (UK) for language perfection and Mrs. Irena Kubečková for excellent technical assistance. The work of A.H. was supported by grant M-01-01-03 and the work of ZM by grant M-01-01-01 of the Ministry of Agriculture of the Czech Republic. V.J. was supported by MŠMT grant J13/98113100004.

\section{REFERENCES}

Ali A. \& GAYlor M.J. 1992: Effects of temperature and larval diet on development of the beet armyworm (Lepidoptera: Noctuidae). Env. Entomol. 21: 780-786.

Ali A., Luttrell R.G. \& Schneider J.C. 1990: Effects of temperature and larval diet on development of the fall armyworm (Lepidoptera: Noctuidae). Ann. Entomol. Soc. Am. 83: $725-733$.

Allen G.R. \& Keller M.A. 1991: Uraba lugens (Lepidoptera: Noctuidae) and its parasitoids (Hymenoptera: Braconidae) temperature, host size, and development. Env. Entomol. 20: $458-469$.

Archer T.L., Musick G.L. \& Murray R.L. 1980: Influence of temperature and moisture on black cutworm (Lepidoptera: Noctuidae) development and reproduction. Can. Entomol. 112: $665-675$.

AYres M.P. \& SCRIBER J.M. 1994: Local adaptation to regional climates in Papilio canadensis (Lepidoptera: Papilionidae). Ecol. Monogr. 64: 465-482.

BAILEY C.G. 1976: Temperature effects on non-diapause development of Mamestra configurata (Lepidoptera: Noctuidae). Can. Entomol. 108: 1339-1334.

BAKER C.R.B. \&. Miller G.W. 1974: Some effects of temperature and larval food on the development of Spodoptera litoralis (Boisd.) (Lep.: Noctuidae). Bull. Entomol. Res. 63: 495-511.

Barbehenn R.V., Reese J.C. \& Hagen K.S. 1999: The food of insects. In: Huffaker C.B. \& Gutierrez A.P. (eds): Ecological Entomology. Wiley, New York, pp. 83-121.

Bauce E., Crepin M. \& Carisey N. 1994: Spruce budworm growth, development and food utilization on young and old balsm fir trees. Oecologia 97: 499-507.

BEACH M.R. \& ToDD J.W. 1988: Development, reproduction, and longevity of Autographa biloba (Lepidoptera: Noctuidae), with observations on laboratory adaptation. Ann. Entomol. Soc. Am. 81: 943-949.

Begon M., Harper J.L. \& Townsend C.R. 1990. Ecology, 2nd ed. Blackwell, Oxford. 945 pp.

Bilapate G.G. \& Thombre U.T. 1979: Effect of constant temperatures on the development of stages of Spodoptera litura F. J. Maharasthra Agric. Univ. 4:1-33.

Bues R. \& Poitout S. 1980: Etude du developpement larvaire et nymphal de Phlogophora meticulosa L. (Lep. Noctuidae) sous differentes interactions controlees de temperatures et de durees d'eclairement. Acta Oecol. Oecol. Appl. 1: 127-138.

Butler G.D. \& Hamilton A.G. 1976: Development time of Heliothis virescens in relation to constant temperature. Env. Entomol. 5: 759-760.
Butler G.D. 1966: Development of the beet armyworm and its parasite Chelonus texanus in relation to temperature. J. Econ. Entomol. 59: 1324-1327.

ButLeR G.D. 1976: Bollworm: development in relation to temperature and larval food. Env. Entomol. 5: 520-523.

Butler G.D., Hamilton A.G. \& Proshold F.I. 1979: Developmental times of Heliothis virescens and H. subflexa in relation to constant temperature. Ann. Entomol. Soc. Am. 72: 263-266.

Butler G.D., Hamilton A.G. \& Bartlett A.C. 1975: Development of the dark strain of cabbage looper in relation to temperature. Env. Entomol. 4: 619-620.

Cabello T. 1988: Influencia de la temperatura y el fotoperiodo en la biologia de Trichoplusia orichalcea F. (Lepidoptera: Noctuidae). Bol. Sanidad Vegetal Plagas 14: 241-247.

Campbell A., Frazer B. D., Gilbert N., Gutierrez A. P. \& MACKAUER M. 1974: Temperature requirements of some aphids and their parasites. J. App. Ecol. 11:431-438.

Cayrol R. 1957: L'effet de groupe sur le développement des larves de Plusia gamma (Lepidoptera-Noctuidae) en corrélation avec differents facteurs du milieu. C. R. Acad. Sci. Paris 245: $580-581$.

CAYROL R. 1962: Interrelations de l'alimentation et des autres facteurs du milieu sur les chenilles de Plusia gamma L. (Lep.: Noctuidae). Ann. Nutr. Aliment. 16: 211-221.

CAYrol R. 1965: Relations existent entre les migrations et le cycle evolutif de certaines espèces de Noctuidae (Insectes, Lépidoptères). C. R. Acad. Sci. Paris 260: 5373-5375.

Combs R.L. \& Valerio J.R. 1980: Biology of the fall armyworm on four varieties of bermudagrass when held at constant temperatures. Env. Entomol. 9: 393-396.

Crawley M.J. 1993. GLIM for Ecologists. Blackwell, London.

David J.R., Moreteau B., Gauthier J.P., Pétavy G., Stockel A. \& IMASHEVA A.G. 1994: Reaction norms of size characters in relation to growth temperature in Drosophila melanogaster: an isofemale lines analysis. Genet. Sel. Evol. 26: 229-251.

DECKER G.C. \& MADDOX J.V. 1971: Effect of temperature on rate of development and survival of Simyra henrici. J. Econ. Entomol. 64: 94-98.

Dixon A.F.G., Hemptinne J.L. \& Kindlmann P. 1997: Effectiveness of ladybirds as biological control agents: patterns and processes. Entomophaga 42: 71-83.

Dostál J. 1989: Nová kvétena ČSSR. (Flora of Czechoslovakia). Academia, Praha, 1548 pp.

Fahmy H.S.M., ZaAzou M.H., Kamel A.A.M. \& El-Hemaesy A.H. 1973: Effect of temperature and humidity on the immature stages of the greasy cutworm, Agrotis ipsilon (Hufn.) (Lepidoptera: Noctuidae). Bull. Soc. Entomol. Egypte 57: 153-164.

Giebink B.L., Scriber M.J. \& Hogg D.B. 1985: Developmental rates of the hop vine borer and potato stem borer (Lepidoptera: Noctuidae): implication for insecticidal control. J. Econ. Entomol. 78: 311-315.

Guppy J.C. 1969: Some effects of temperature on the immature stages of the armyworm, Pseudaletia unipuncta (Lepidoptera: Noctuidae), under controlled conditions. Can. Entomol. 101: 1320-1327.

Hagstrum D.W. \& Mrluriken G.A. 1988: Quantitative analysis of temperature, moisture and diet factors affecting insect development. Ann. Entomol. Soc. Am. 81: 539-546.

Hammond R.B., Poston F.L. \& Pedigo L.P. 1979: Growth of the green cloverworm and a thermal-unit system for development. Env. Entomol. 8: 639-642.

Hasegawa T. \& ChiBA T. 1969: Relations of temperature to the development of the egg and larval stage of Agrotis ipsilon and 
Agrotis fucosa (Preliminary report). Jap. J. Appl. Entomol. Zool. 13: 124-128

Hill J.K. \& Gatehouse A.G. 1992: Effects of temperature and photoperiod on development and pre-reproductive period of the silver Y moth Autographa gamma (Lepidoptera: Noctuidae). Bull. Entomol. Res. 82: 335-341.

HrRar K. 1975: The influence of rearing temperature and density on the development of two Leucania species, L. loreyi Dup. and L. separata Walker (Lepidoptera: Noctuidae). Appl. Entomol. Zool. 10: 334-237.

HoNĚK A. 1997: Incidence of protogynous and protandrous development in the pre-imaginal stage of insect development: an overview. Acta Soc. Zool. Bohem. 61: 113-128.

HoNĚK A. 1996: The relationship between thermal constants for insect development: a verification. Acta Soc. Zool. Bohem. 60: $115-152$.

HoNĚK A. 1999: Constraints on thermal requirements for insect development. Entomol. Sci. 2: 615-621.

HonĚK A. \& KoCOUREK F. 1990: Temperature and development time in insects: a general relationship between thermal constants. Zool. Jb. Syst. 117: 401-439.

HonĚK A., MartinKová Z. \& LipavsKá H. 1998: Distribution of Metopolophium dirhodum in maize and cereals. In: Nieto Nafría J.M. \& Dixon A.F.G. (eds): Aphids in Natural and Managed Ecosystems. Universidad de Leon, Spain, pp. $569-578$.

Isenhour D.J., Wiseman B.R. \& Widstrom N.W. 1985: Fal armyworm (Lepidoptera: Noctuidae) feeding responses on corn foliage and foliage/artificial diet medium mixtures at different temperatures. J. Econ. Entomol. 78: 328-332.

JACKSON C.G., BUTLER G.D. \& BRYAN D.E. 1969: Time required for development of Voria ruralis and its host, the cabbage looper, at different temperatures. J. Econ. Entomol. 62: $69-70$.

JARošíK V., HonĚK A. \& Dixon A.F.G. in pres.: Developmental rate isomorphy in insects and mites. Ann. Nat. (accepted).

Judd G.J.R., Cossentine J.E., Gardiner M.G.T. \& Thomson D.R. 1994: Temperature dependent development of the speckled green fruitworm, Orthosia hibisci Guenee (Lepidoptera: Noctuidae). Can. Entomol. 126: 1263-1275.

KAMM J.A. 1991: Larval development of Dargida procincta (Grote) (Lepidoptera: Noctuidae) in the Pacific Northwest. Pan-Pac. Entomol. 67: 20-23.

KirITANi K. 1997: The low development threshold temperature and the thermal constant in insects, mites and nematodes in Japan. Misc. Publ. Nat. Inst. Agro-Environ. Sci. 21: 1-72.

KozHANTSHIKov V.I. 1993: Effect of temperature and humidity on development of Phytometra gamma L. Zashch. Rast. 14: 49-61. [in Russian]

Leprla N.C., Ashley T.R., Guy R.H. \& Butler G.D. 1977 Laboratory life history of the velvetbean caterpillar. Ann. Entomol. Soc. Am. 70: 217-220.

LEVINE E. 1983: Temperature requirements for development of the stalk foser, Papaiperua nebris (Lepidoptera: Nochidae). Ann. Entomol. Soc. Am. 76: 892-895.

Lindroth R.L., Barman M.A. \& Weisbrod A.V. 1991: Nutrient deficiencies and the gypsy moth, Lymantria dispar: effects on larval performance and detoxication enzyme activities. $J$. Insect Physiol. 37: 45-52.

LONG D.B. 1953: Effects of population density on larvae of lepidopters. Trans. R. Entomol. Soc. London 104: 541-591.

LoNG D.B. 1955: Observations on sub-social behaviour of two species of lepidopterous larvae, Pieris brassicae L. and Plusia gamma L. Trans. R. Entomol. Soc. London 106: 421-437.
LoNG D.B. 1959: Observations on adult weight and wing area in Plusia gamma L. and Pieris brassicae L. in relation to larval population density. Entomol. Exp. Appl. 2: 241-248.

Luckmann W.H., Shaw J.T., Sherrod D.W. \& Ruesnik W.G. 1976: Developmental rate of the black cutworm. J. Econ. Entomol. 69: 386-388.

Merkel G. 1977: The effect of temperature and food quality on the larval development of Gryllus bimaculatus (Orthoptera: Gryllidae). Oecologia 30: 129-140.

Miller J.C., West K.J. \& Hanson P.E. 1984: Temperature requirements for development of Autographa californica (Lepidoptera: Noctuidae). Env. Entomol. 13: 593-594.

MrYASHITA K. 1971: Effects of constant and alternating temperatures on the development of Spodoptera litura F. (Lep.: Noctuidae). Appl. Entomol. Zool. 6: 105-111.

NADGaUdA D. \& Pitre H. 1983: Development, fecundity, and longevity of the tobacco budworm (Lepidoptera: Noctuidae) fed soybean, cotton, and artificial diet at three temperatures. Env. Entomol. 12: 582-586.

Nasr E.S.A., El-Rafie K., Hosny M.M. \& Badawi A. 1973: Effect of temperature and relative humidity on the life-cycle of the cotton leafworm Spodoptera littoralis (Boisd.) (Lepidoptera: Noctuidae). Bull. Soc. Entomol. Egypte 57: 139-144.

NAWROT J. 1979: Effect of temperature and relative humidity on population parameters for almond moth (Cadra cautella Wlk.) (Lepid. Phycitidae). Prace Nauk. Inst. Ochr. Roslin. Poznan 21: 41-51.

Novák I. 1960: Beitrag zur Bionomie der Gammaeule (Plusia gamma L. - Insecta: Lep.). Zoologické Listy 9: 19-33. [in Czech, German summ.]

NovÁK I. 1971: The hibernation of the Silver Y- moth (Autographa gamma L.) (Lepidoptera: Noctuidae) under the climatic conditions of central Europe. Proc. XIIIth Internat. Congr. Entomol. Moscow p. 533.

NovÁK I. 1972: Hibernation of Autographa gamma L. (Lep.: Noctuidae) in Central Europe. Ochrana Rostlin 8: 305-312. [in Czech, English summ.]

Novák I. 1974: A contribution to the food relationship in Autographa gamma L. (Lep.: Noctuidae). Sbor. Věd. Praci IV Celost. Konf. Ochr. Rostlin. Bratislava, pp. 141-147. [in Czech, English summ.]

Novák I. 1976: Quelques rélations existant entre diapause et migration chez Autographa gamma L. et quelques autres espèces de noctuelles. Ann. Zool. Ecol. Anim. 8: 389-391.

NovÁK I. 1988: Annual cycle of silver-Y moth (Autographa gamma L., Lep., Noctuidae) under climatic conditions of central Europe. Proc. XI. Czechoslovak Plant Protect. Conf. Nitra, pp. 149-150. [in Czech, English summ.]

NYlin S. \& GotthaRd K. 1998: Plasticity in life-history traits. Annu. Rev. Entomol. 43: 63-83.

Nylin S., Wiklund C., Wickman P.O. \& Garcia-Barros E. 1993: Absence of trade-offs between sexual size dimorphism and early male emergence in a butterfly. Ecology 74: $1414-1427$.

OStREYKóWNa M. 1924: [Morphology and biology of Plusia gamma]. Prace Zakl. Zool. Univ. St. Bat. Wilnie 6: 1-66. [in Polish]

Portout S. \& Bues R. 1974: Elevage de chenilles de vingt-huit espèces de Lépidoptères Noctuidae et de deux espèces d'Arctiidae sur milieu artificiel simple. Ann. Zool. Ecol. Anim. 6: 431-441.

Ponder K.L., Pritchard J., Harrington R. \& Bale J.S. 2000: Difficulties in location and acceptance of phloem sap combined with reduced concentration of phloem amino acids explain lowered performance of the aphid Rhopalosiphum 
padi on nitrogen deficient barley (Hordeum vulgare) seedlings. Entomol. Exp. Appl. 97: 201-210.

Quareshi M.H., Murai T., Yoshida H., Shiraga T. \& Tsumuk H. 1999: Effect of photoperiod and temperature on development and diapause induction in the Okayama population of Helicoverpa armigera (Hb.) (Lepidoptera: Noctuidae). Appl. Entomol. Zool. 34: 327-331.

Rao G.V.R., Wightman J.A. \& Rao D.V.R. 1989: Threshold temperatures and thermal requirements for the develpment of Spodoptera litura (Lepidoptera: Noctuidae). Env. Entomol. 18: $548-551$.

SANDs D.P.A., Scholtz M. \& Bourne A.S. 1991: Effects of temperature on development and seasonality of Eudocima salaminia (Lepidoptera: Noctuidae) in eastern Australia. Bull. Entomol. Res. 81: 291-296.

Schmidt D.J. \& ReEse J.C. 1988: The effects of physiological stress on black cutworm (Agrotis ipsilon) larval growth and food utilization. J. Insect Physiol. 34: 5-10.

Scrwitulla H. 1963: Zur Gradation der Gammaeule Phytometra (Plusia) gamma L. Z. Pflkrkh. Pflschutz 70: 513-532.

SCRIBER J.M. 1977: Limiting effects of low leaf-water content on the nitrogen utilization, energy budget, and larval growth of Hyalophora cecropia (Lepidoptera: Saturniidae). Oecologia 28: 269-287.

SCRIBER J.M. 1979a: Effects of leaf-water supplementation upon post-ingestive nutritional indices of forb-, shrub-, vine- and tree-feeding Lepidoptera. Entomol. Exp. Appl. 25: 240-252.

SCRIBER J.M. 1979b: Post-ingestive utilization of plant biomass and nitrogen by Lepidoptera: legume feeding by the southern armyworm. J. N. Y. Entomol. Soc. 87: 141-153.

SCRIBER J.M. 1996: A new "Cold Pocket" hypothesis to explain local host preference shifts in Papilio canadensis. Entomol. Exp. Appl. 80: 315-319.

Sharma S.K. \& Chaudhary J.P. 1988: Effect of different levels of constant temperature and humidity on the development and survival of Heliothis armigera (Hubner). Indian J. Entomol. 50: 76-81.

SHIELDS E.J. 1983: Development rate of variegated cutworm (Lepidoptera: Noctuidae). Ann. Entomol. Soc. Am. 76: 171-172.

Sidibé B. \& LaUGge G. 1977: Incidence de thermoperiodes et de températures constantes sur quelques critères biologiques de Spodoptera littoralis Boisduval (Lepidoptera: Noctuidae). Ann. Soc. Entomol. Fr. (N.S.) 13: 369-379.

Simonet D.E., Clement S.L., RubinK W.L. \& Rings R.W. 1981: Temperature requirements for development and oviposition of Peridroma saucia (Lepidoptera: Noctuidae). Can. Entomol. 113: 891-897.

SINCHAISRI N. \& SogaWA K. 1969: The influence of temperature on the development of armyworm, Leucania separata,
Walker (Lepidoptera: Noctuidae). Appl. Entomol. Zool. 4: 102-103.

SLANSKY F. 1993: Nutritional ecology: the fundamental quest for nutrients. In: Stamp N.E. \& Casey T.M. (eds): Caterpillars. Chapman \& Hall, New York, pp. 29-91.

SlansKY F. \& SCRIBER J.M. 1985: Food consumption and utilization. In: Kerkut G.A. \& Gilbert L.I. (eds): Comprehensive Insect Physiology, Biochemistry and Pharmacology, Vol. 4. Pergamon, Oxford, pp. 87-163.

SMITH A.M. 1984: Larval instar determination and temperaturedevelopment studies of immature stages of the common armyworm, Mythimna convecta (Walker) (Lepidoptera: Noctuidae). J. Aust. Entomol. Soc. 23: 91-97.

SoOnTIENs J. \& BinK F.A. 1997: Developmental response of Coenonympha pamphilus (Lepidoptera: Satyrinae) to differences in nitrogen and water content of grasses. Proc. Sect. Exp. Appl. Entomol. Netherel. Entomol. Soc. 8: 29-36.

STEUdEL W. 1963: Einige Beobachtungen bei der Aufzucht von Raupen der Gammaeule (Phytometra gamma L.) im Laboratorium. Nachrbl. Dt. Pflschutz Braunschweig 15: 152-154.

StatSoft 1994: Statistica for Windows (Volume I): General Conventions and Statistics I. StatSoft, Inc., Tulsa.

TAYLOR P.S. \& SHIELDS E.J. 1990: Development of the armyworm (Lepidoptera: Noctuidae) under fluctuating daily temperature regimes. Env. Entomol. 19: 1422-1432.

Toba H.H., Kishaba A.N., Pangaldan R. \& Vail P.V. 1973: Temperature and development of the cabbage looper. Ann. Entomol. Soc. Am. 66: 965-974.

TwINE P.H. 1978: Effect of temperature on the development of larvae and pupae of the corn earworm, Heliothis armigera (Hubner) (Lepidoptera: Noctuidae). Queensl. J. Agric. Anim. Sci. 35: 23-28.

Weismann L. \& Podmanická D. 1971: Einfluss der Temperatur und Nahrung auf die Entwicklung der Wintersaateule Scotia segetum (Dennis et Schiffermuller). Biol. Práce 17: 1-75.

WikLund C., NYLIN S. \& ForsBerg J. 1991: Sex-related variation in growth rate as a result of selection for large size and protandry in a bivoltine butterfly (Pieris napi L.). Oikos 60: 241-250.

WISEMAN B.R. \& ISENHOUR D.J. 1989: Effects of temperature on development of corn earworm (Lepidoptera: Noctuidae) on meridic diets of resistant and susceptible corn silks. Env. Entomol. 18: 683-686.

Wu K.C., Chen Y.P. \& Lr M.H. 1980: Influence of temperature on the growth of laboratory populations of the cotton bollworm, Heliothis armigera (Hübner). Acta Entomol. Sin. 23: 358-368.

Received November 9, 2001; revised March 1, 2002; accepted April 12, 2002 